\title{
AYPICAL EXAMPLE OF MENTAL REGION-BUILDING? THE BALKAN AREA IN FINNISH SCHOOLBOOKS FROM THE LATE 19TH CENTURY TO THE BEGINNING OF THE 21ST CENTURY
}

\section{Kari Alenius}

University of Oulu, E-Mail: kari.alenius@oulu.fi

\begin{abstract}
:
Schoolbooks play a crucial role in the formation of one's world view. This study analyzes how the Balkan area has been depicted in Finnish schoolbooks under the existence of the modern school system from the 1870s to the 2000s. For this study, all history and geography schoolbooks published in Finland have been examined. Of books of which there are several editions, at least the first and the last editions and any other necessary ones have been used.

The familiarization of Finnish school children with the Balkan countries and peoples has occurred through two subjects, history, and foremost, through geography. Descriptions and interpretations relating to the Balkan area and its inhabitants have existed in Finnish schoolbooks from the beginning. During approximately 140 years, the amount of description and content has changed in some respects, but on the other hand, elements of clear continuity and immutability are apparent.
\end{abstract}

\section{Rezumat:}

Manualele școlare joacă un rol crucial în formarea viziunii despre lume. Acest studiu analizează modul în care zona Balcanilor a fost descrisă în manualele școlare finlandeze în perioada sistemului școlar modern, de la 1870 la 2000. Pentru intocmirea acestui articol au fost examinate toate manualele de istorie și geografie publicate în Finlanda. In cazul cărților care au cunoscut mai multe ediții, au fost utilizate cel puțin prima și ultima ediție și oricare altele considerate necesare.

Familiarizarea elevilor finlandezi cu țările și popoarele balcanice a avut loc prin intermediul a două discipline, istorie, și în primul rând prin geografie. Descrieri și interpretări cu privire la zona Balcanilor și locuitorii săi au existat în manualele școlare finlandeze încă de la început. In perioada de aproximativ 140 de ani, cantitatea de descriere și conținutul s-au schimbat în anumite privințe, dar, pe de altă parte, elementele de continuitate clară și imutabilitatea sunt evidente. 
Keywords: The Balkans, Finland, images, stereotypes, schoolbooks, education

\section{Introduction}

The aim of this study is to analyze what kind of image Finnish schoolbooks have provided of the Balkan area and why this image has been a certain kind. The analysis focuses on the key features of this image and the most pertinent factors that could explain it. It is apparent that the basic nature of this image has largely remained the same from generation to generation. The time span of the study begins with the birth of the modern Finnish school system and continues to the modern day; in other words, it covers the period from the 1870s to the 2000s. Representations of foreign countries and other cultures in Finnish schoolbooks have been studied to some extent, but the image of the Balkans as part of this subject matter has so far been unexplored.

Schoolbooks and education have an important role in the formation of people's worldviews. Images of foreign people, countries, areas, and cultures are largely based on what is taught in school. The importance of analyzing these images is emphasized by the fact that images have a very significant impact on people's behavior. Although images may not necessarily be "true" or "correct", their effects are real, as people believe that their views reflect reality. There is also reason to note that views are long term, and that once they are born they do not change easily. Change usually requires a very powerful new factor that causes established views to change, or alternatively, change requires the long-term accumulation of less information. Usually however, people have a tendency to choose information that supports their existing views when presented with conflicting information. ${ }^{1}$

Images are inevitably subjective, and in addition to being influenced by "facts", they are influenced by an individual's beliefs, attitudes, hopes and fears - in short, the whole experience of the individual. In addition to factors related to the personality of an individual, a wide range of social contexts affect the creation of views. For instance, the social and moral

\footnotetext{
1 Olavi K. Fält, "Introduction," in Looking at the Other. Historical study of images in theory and practise. Edited by Kari Alenius, Olavi K. Fält \& Seija Jalagin (Oulu: University of Oulu, 2002), 8-11; Kenneth J. Gergen and Mary M. Gergen, Social psychology (New York: Springer Verlag, 1986), 46-51; David Ratz, 'The Study of Historical Images', Faravid 31/2007, 189, 199, 218. 
developments of one's own country as well as corresponding political, economical, social, religious and intellectual developments in the world are factors that affect the formation of worldviews and as part of this, the formation of the content of schoolbooks. ${ }^{2}$ Within this study it is not possible to comment on the extent to which the education given in school has differed from the content of schoolbooks. However, by default it can be considered that teachers have essentially taught along the same lines as the content in schoolbooks. This study also does not take a position on the extent to which the views of schoolchildren were identical to the content of schoolbooks or to what extent other factors have contributed to the formation of views. The broadening and diversification of information towards the present time has undoubtedly reduced the significance of schoolbooks and school education.

In any case, the focus of this study is on the analysis of the content in schoolbooks, and not on the view of the Balkans actually adopted by Finnish schoolchildren. We can only assume that schoolbooks are material that has likely affected schoolchildren. As such, above all, the content of schoolbooks reflects the worldview and purpose of intent of their authors and those that have directed them (for instance, the Ministry of Education). Just as little as any other human communication is a pure neutral transmission of information, school education is inextricably linked to the purpose of intent that appears in the selection of information, points of emphasis, and in formation. ${ }^{3}$ Measuring the impact on schoolchildren is a separate subject of study that would require the study of large-scale interviews. Such material over these decades does not exist and cannot be created afterwards, at least not without the possibility of great distortion.

In short, it can be said that the content of Finnish schoolbooks reflects the view of the Balkans of those who created them, as well as their attitude towards the outside world and diversity. Although there are many permanent elements in these images, there are also changes in emphasis and tone. Based on the changes found in this analysis, development can be divided into four successive stages. The first period includes the last decades

\footnotetext{
2 Fält 2002, 10-11; Ratz 2007, 199-203; Raphael Samuel and Paul Thompson, "Introduction," in The Myths We Live By, ed. by Raphael Samuel and Paul Thompson (London: Routledge, 1990), 4 .

${ }^{3}$ Manfred Beller, "Perception, image, imagology," in Imagology. The cultural construction and literary representation of national characters. A critical survey, ed. by Manfred Beller and Joep Leerssen (Amsterdam: Rodopi, 2007), 4-7; Fält 2002, 10.
} 
of the 1800s until approximately the end of the First World War. The second period extends from the early years of the 1920s to the 1950s. The third period extends from the 1960s to the 1980s and the fourth includes the last two decades.

Finnish perceptions of the Balkans through a historical perspective are an almost unexplored topic. Closest to the theme of this study is Johanna Tilkanen's M.A. thesis (2011) which examines the image of the Balkans in Finnish travel literature during the interwar period. Although Tilkanen's work has not examined schoolbooks, her work suits this study as a reference, particularly for the 1920s and 1930s. According to Tilkanen's findings, Finnish travel literature largely reflected old cultural and national stereotypes, often with an emphasis on "Easternness" and "underdevelopment". ${ }_{4}^{4}$ As such, the images of Finnish travel literature largely reflected the image of the Balkan area that was prevalent in Western and Northern Europe, without any special Finnish features. For instance Maria Todorova has examined the broader historical development of the Balkan image in Europe in her work "Imagining the Balkans" (updated version 2009). ${ }^{5}$ This can be compared to the image of the Balkans in Finnish schoolbooks.

The content of Finnish schoolbooks and the worldview that they mediated has been examined in the last decades, although quite little. The majority of studies are Master's level theses, but a few dissertations have appeared, too. None of these deal with the image portrayed of the Balkan area, but on the other hand some of these publications are suitable as reference for this study. ${ }^{6}$ They can be used to understand the worldview of Finnish schoolbooks and the general development of contents concerning other countries from a broad perspective. They can be used, for instance, to consider whether changes in description concerning the Balkan area have

\footnotetext{
4 Johanna Tilkanen, Vierailulla "epä-Euroopassa". Balkan-kuva suomalaisessa matkakirjallisuudessa maailmansotien välisenä aikana (Turku: Turun yliopisto, 2011), 82-85.

${ }^{5}$ Maria Todorova, Imagining the Balkans (Oxford: Oxford University, 2009).

6 See, for instance, Susanna Hemminki, Uskonnon värittämä ikivanha kulttuuri, vastakohtaisuuksien sävyttämä jakaantunut yhteiskunta. Intia-kuva suomalaisissa maantiedon oppikirjoissa vuosina 1921-1972, (Oulu: Oulun yliopisto, 2005); Janne Holmén, Den politiska läroboken. Bilden av USA och Sovjetunionen i norska, svenska och finländska läroböcker under Kalla kriget (Uppsala: Uppsala universitet, 2006); Anu Kukkonen, Pustalla ei ole polkua. Unkari-kuva äidinkielen oppikirjoissa (Jyväskylä: Jyväskylän yliopisto, 2003); Sanna Rantahäli, "Ahkeran vaatimattoman kansan iätön sivistysmaa". Kiina-kuva suomalaisissa maantiedon oppikirjoissa vuosina 1921-1972 (Oulu: Oulun yliopisto, 2003).
} 
progressed at the same pace as changes in image concerning other areas, or whether differences can be detected (and if so, why). In short, research concerning changes in the content of schoolbooks contributes to understanding certain characteristics of the Balkan image.

\section{The birth of basic negative elements in the Balkan image (from the 1870s to the 1920s)}

Regular schooling expanded and became established in Finland to cover all social groups during the second half of the 1800s. The most important legislative reforms concerning this were made in the $1860 \mathrm{~s}$ and 1870s. ${ }^{7}$ At the same time, new schoolbooks were created for the number of schoolchildren, which had multiplied, and with slight modifications these were used in Finnish schools until the 1920s. From the perspective of this article, this selection of books can be considered the first generation of Finnish schoolbooks.

A permanent feature of Finnish school textbooks from the 1800s to the present has been that Balkan history has been featured very little. On one hand, the teaching of history has always focused on domestic history, and on the other, on what have been considered the most important world developments and great powers. In European history, emphasis has been put on ancient history and Western European (Great Britain, France and Germany) history. None of these elements have favoured the rise of Balkan history in the texts of Finnish history textbooks. In practice, the Balkans has only been briefly mentioned in the context of the world wars and even then, there is generally only a listing of which side Balkan states have fought on in the world wars. In maps presenting the chronology of the world wars, the same thing is presented in visual form. ${ }^{8}$

Before the First World War, the only thing related of Balkan history in Finnish schoolbooks was the liberation of countries from Turkish rule (Ottoman Empire) in the latter half of the 1800s. The gradual decline of the Ottoman Empire at the end of the 1800s and early 1900s was a recent and

\footnotetext{
7 Kyösti Kiuasmaa, Oppikoulu 1880-1980. Oppikoulu ja sen opettajat koulujärjestyksestä peruskouluun (Oulu: Pohjoinen, 1982), 86-91; Martti T. Kuikka, Suomalaisen koulutuksen vaiheet (Helsinki: Otava, 1991), 51-60.

8 Sirkka Ahonen et al., Koulun historia 8 (Helsinki: Otava, 1987), 15, 98;Osmo Lappalainen et al., Horisontti. Historia Napoleonista nykypäivään (Helsinki: Otava, 1998), 173, 254; Oskari Mantere \& Gunnar Sarva, Keskikoulun yleinen historia II (Porvoo: WSOY, 1961), 331-332, 353 355.
} 
significant enough happening in European history that it exceeded the publication threshold of schoolbooks. ${ }^{9}$ In addition, from a Finnish perspective, the war of 1877-1878 was particularly interesting, as Finnish units took part as part of the Russian armed forces (the so-called Finnish Guards). This was the first time that Finns participated in military action since 1831. The direct link to Finland's own history understandably contributed to its inclusion in schoolbooks.

This "Turkish war", as it was called in Finland, was the only event relating to Balkan history that was recommended for consideration in all history textbooks by the first national schoolbooks committee report completed in Finland in 1899.10 The matter was also made timely by the fact that there was a desire to present the Turkish war as a noble attempt of assistance on the part of the Russian Empire, in particular of Tsar Alexander II, the purpose of which was to liberate the Balkan Christians from the domination of Muslim "infidels". ${ }^{11}$ The textbook committee stressed the importance of teaching Christian values as part of education in all schools, 12 and from a broader perspective, there was room to make a sharp distinction between Christianity and "pagan" religions in the attitude of the time. Thus, in Finnish schoolbooks, at the end of the 1800s and beginning of the 1900s, the Balkans appeared as a scene of interreligious war in which the true faith was overcoming the wrong faith.

Descriptions of the Turkish war were shortened or eliminated from Finnish schoolbooks after the First World War. Finnish participation in the war of 1877-1878 was preserved as an interesting curiosity that could be briefly mentioned. ${ }^{13}$ At the same time, changes in the Balkan states during

\footnotetext{
${ }^{9}$ O. A. Hainari, Yleisen historian oppikirja kansakouluja varten (Jyväskylä: Gummerus, 1911), 131132, 138-139; H. L. Melander, Lärobok $i$ allmän historia for realskolor och fruntimmersskolor (Helsingfors: K. E. Holms förlag, 1875), 146-147; O. Wallin, Yleisen historian oppikirja. Kansakouluja varten (Helsinki: Weilin \& Göös, 1898), 101; V. K. E. Wichmann \& V. Rihtniemi, Yleisen historian oppikirja seminaareja y.m. opistoja varten (Helsinki: G. W. Edlund, 1914), 153, 177.

10 Suunnitelmia Suomen kansakoulujen Oppi- ja Lukukirjoja varten. Tarkoitusta varten asetetun komitean Mietintö (Raahe: Rob. Rossander, 1899) (hereafter cited as Suunnitelmia 1899), 72.

11 Hainari 1911, 138-139; K. O. Lindeqvist, Uuden ajan historian oppikirja (Porvoo: WSOY, 1913), 262; Wichmann \& Rihtniemi 1914, 175.

12 Suunnitelmia 1899, 22-24.

13 F. A. Hästesko, Historian oppikirja kansakouluja varten (Porvoo: WSOY, 1931), 177; Einar W. Juva et al., Isänmaan historia (Helsinki: Otava, 1938), 209; Sakari Kuusi \& Lauri Elimäki, Kansakoulun historian oppikirja (Jyväskylä: Gummerus, 1951), 218-220. 
the 1800 s were mentioned or presented on a map. ${ }^{14}$ However, the First World War was a significant enough event that it largely buried discussion of Balkan developments during the 1800s in Finnish schoolbooks. As well, the glorification of Tsar Alexander II's policy in the Balkans had no political emphasis after Finland gained independence from Russia in 1917.

Well over ninety percent of the material in Finnish schoolbooks focusing on the Balkans can be found in geography textbooks, therefore in this study there is reason to focus on analyzing them. Geography textbooks have provided basic information on the natural conditions of each country, as well as the creation of each state. Information on social basics from the 1800s to the present day have consisted largely of four categories: the people (language, ethnic issues), the social system (form of government, governance), culture (religion, customs, mentality), and economy (livelihood, industries, standard of living). The amount of text concerning the Balkans has varied depending on the book and the period under review from about one page to five pages, including any images, statistics, maps and text.

The room given to Balkan countries combined has been more or less comparable to that given to Western or Central European great powers, for instance that given to France. This is due to various updated guidelines that were provided by national educational textbook committees (or equivalent regulatory bodies). According to the directions given, until the 1980s, geography textbooks, like history textbooks, were recommended or even directed to focus on the most "important" countries in Europe and the world in addition to Finland. In addition, there were directions to place more attention on Finland's neighboring areas than on more distant countries. ${ }^{15}$ These directions either have never favoured any focus on the Balkans. On the other hand, a brief presentation of all European states and areas has always been required in geography textbooks; therefore completely ignoring the Balkans has not been possible. By granting a few pages of attention to the Balkan states, textbook writers have followed instructions very conscientiously.

\footnotetext{
14 Hästesko 1931, 175-177; Juva et al. 1938, 208-210; O. Mantere \& G. Sarva, Keskikoulun yleinen historia II (Porvoo: WSOY, 1926), 304-305; Y. I. Ora \& A. K. Ottelin, Historian oppikirja keskikouluille III (Helsinki: Otava, 1946), 160, 194.

15 See, for instance Suunnitelmia 1899, 65-76; Peruskoulun opetussuunnitelman perusteet (Helsinki: Kouluhallitus, 1985), 131-143, 165-172.
} 
The definition of the Balkan region presents another issue. Government regulations that have directed the content of schoolbooks have never taken a direct stand on where the borders of the "Balkans" are specifically located. Taking a more comprehensive review of the issue, there has not been complete unanimity over the question in Finland or anywhere else. This uncertainty has always been reflected in Finnish geography textbooks. Even in the first generation of schoolbooks from 1870-1890 there was no clarity on this issue. All of the books were of the same opinion that all of the European areas of the Ottoman Empire - Greece, Bulgaria, Serbia and Montenegro (and later Albania) - belonged to the Balkans, and that Austria-Hungary did not belong to it. The borders of these two great powers, particularly in relation to Romania and Bosnia-Herzegovina, were difficult to categorize.

The most common interpretation was that the Danube formed the natural northern border of the Balkan region, in which case Romania was left outside of the Balkans. ${ }^{16}$ However, in a few older books, this interpretation was the opposite. ${ }^{17}$ The national guidelines drawn up in 1899 indirectly referred to the latter interpretation, as Southeast Europe was to be known as "Austria-Hungary and the Balkan Peninsula". ${ }^{18}$ However, the writers of Finnish geography textbooks stuck with the interpretation of geography from the early 1900s that considered natural geography. According to that Romania was not included in the Balkans but it was included as part of "the countries of the Danube region", the core of which was Austria-Hungary.

At the end of the 1800s and beginning of the 1900s the goal of geography education was not only to describe the living conditions around the world, but also to give encouraging examples of how, through diligent work and inventiveness, people were able to control nature and survive in a wide range of environments and conditions, ${ }^{19}$ or perhaps in some cases to give warning examples of the opposite. Thus, education served as a general civic education, in which the goal was to create good workers of

\footnotetext{
16 J. E. Aro \& J. E. Rosberg, Koulun maantieto (Helsinki: Otava, 1908), 90; O. A. Forsström, Kansakoulun maantieto (Helsinki: Weilin \& Göös, 1901), 124-127; August Kanninen, Kansakoulun maantieto (Tampere: H. T. Bärlund, 1895), 48; Elis Lagerblad, Lärobok i geografi (Borgå: Werner Söderström, 1890), 113.

17 Ed. Erslev, Lärobok i geografin (Wiborg: Clouberg, 1882), 131-135; A. E. Modeen, Oppikirja maantieteessä (Wiipuri: Clouberg ja kump., 1886), 136-141.

18 Suunnitelmia 1899, 80.

19 Suunnitelmia 1899, 74.
} 
schoolchildren who were loyal to their homeland. The guidelines of 1899 also referred to such objectives. "Awakening love for their own people and country" as well as a closely related Christian moral education was an essential part of all education, including not only geography but also religion, mother tongue, history, mathematics, etc. ${ }^{20}$

In the portrayal of the Balkans, these objectives were reflected in the schoolbooks of the time in several ways. The books put a lot of emphasis on natural conditions, from the perspective of what kinds of limitations geography and environment put on the pursuit of a livelihood. The main focus was on the operating conditions of agriculture, which was understandable as at the beginning of the 1900s agriculture was clearly the main livelihood in Finland and employed about $80 \%$ of the labour force. The main agricultural products of the Balkans were generally found in tables in the books. At the same time, some kind of general assessment as to the degree of development of agricultural and of industry in general was almost always provided. During the 1800s and beginning of the 1900s these general assessments were without exception always slightly negative. In some books, briefly and without an explanation, it was found that the economy in the Balkans was "in bad shape". ${ }^{21}$ Part of the books referred to explanatory factors such as the mountainous region and the low level of education of the people. ${ }^{22}$

The overall impression formed by all schoolbooks was that the Balkan people were uneducated and poor and had to struggle to attain their livelihood. Part of this was explained by the natural conditions of the area, but even more so by social underdevelopment. In the same context, there was often reference to "Eastern" governance and culture, which was seen as favouring bureaucracy and complicating the sensible way of doing things. ${ }^{23}$ One major factor that was provided was the fatalism that was attributed to Muslims, which was seen to cause laziness and indifference. ${ }^{24}$ Such problems were seen to be rooted in the Turkish domination of the Balkan area, without any separation between Christians and Muslims. A few books directly

\footnotetext{
20 Suunnitelmia 1899, 22, 33, 54, 65, 74, 82.

21 Alfred Jotuni, Kansakoulun maantiede (Porvoo:WSOY, 1916), 107-109; Kanninen 1895, 63; Modeen 1886, 138-139.

22 Aro \& Rosberg 1908, 174; Lagerblad 1890, 148-151.

23 Aro \& Rosberg 1908, 174; Lagerblad 1890, 153.

24 Forsström 1898, 127; Lagerblad 1890, 150; Modeen 1886, 139.
} 
referred to Turkey as the "sick man of Europe" 25 - a figure of speech that became common in other parts of Europe, in particular during the late years of the 1800 s. ${ }^{26}$

One positive side of the alleged fatalism of Muslims was seen to be the fact that they did not fear death, which made them brave on the military field. ${ }^{27}$ This reflected the militaristic ideals of the time and the value placed on military fitness, both of which were part of broader educational goals. The traits of a "good citizen" included not only diligence and perseverance in peacetime work, but a similar kind of sacrifice in fulfilling wartime obligations. However, in the case of the Balkans this part of the image was also negative, as the Balkan peoples were described from the beginning of the 1890s as being so belligerent and violent that it was thought to produce unrest in the area and hinder the construction of an orderly and prosperous society. Albanians and Montenegrins particularly were openly referred to as violent and "half wild" tribes that were quite far from the European ideal of educated man. 28

References to the unrest and belligerence of the Balkans were missing from the earliest Finnish schoolbooks of the 1880s. ${ }^{29}$ One explanation for this might be that books then were markedly slimmer and more succinct than a couple of decades later, so there was less material to be found that adopted any position in books. On the other hand, it could be that stereotypes regarding the Balkans as a place of unrest had not yet been established in the 1880s. The crises and changes of state borders near the end of the century strengthened the emerging conception, and the Balkan wars in 1912-1913 with the birth of the First World War in the Balkans created the basis for the final stereotype. Thus, the content of Finnish schoolbooks indicates that the belief of the Balkans as an age-old place of unrest and as "the powder keg of Europe" is, however, quite fresh and does not extend much further than the late $19^{\text {th }}$ and the early $20^{\text {th }}$ century in history. ${ }^{30}$

Greece was a slight exception of how the Balkans was generally described in the late 1800s and early 1900s in Finnish geography textbooks.

\footnotetext{
${ }^{25}$ Erslev 1882, 133; Modeen 1886, 139.

${ }^{26}$ Dimitris Livanios, 'The 'sick man' paradox: history, rhetoric and the 'European character' of Turkey', Journal of Southern Europe and the Balkan, Vol. 8, Number 3 (2006), 299-300.

27 Aro \& Rosberg 1908, 174; Lagerblad 153.

28 Jotuni 1916, 108; Kanninen 1895, 64; Lagerblad 1890, 152.

29 See, for instance, Modeen 1886.

30 Cf. Todorova 2009, 7-19, 116-123. 
In the case of Greece, the ancient high culture was almost always mentioned, ${ }^{31}$ and this admiration in science and art circles was general at the end of the late 1800s and early 1900s. For instance, in history education ancient Greece received a lot of positive attention in comparison to almost any later stage of European history. ${ }^{32}$ Geography textbooks did not discuss ancient Greek history, but the ancient achievements of the country clearly bestowed some degree of glory on its present-day people residing there some 2000 years later in the same area, in the minds of textbook writers. Greek people were additionally discussed as skilled mariners and "cunning" tradespeople who, thanks to their skills, were able to obtain additional income. ${ }^{33}$ Apparently, this was to encourage Finnish schoolchildren to enterpreneurship and diversification of economic activity. Increasing foreign trade was clearly one way.

At any case, Finnish schoolbooks clearly evaluated the Balkans as being more alien, inferior and underdeveloped than any core areas of Europe were considered. As in the image of the Balkans in general, observed real differences were exaggerated and emphasized in order to achieve a clear polarization. The "Turkish", "Eastern" and if not religiously, than at least culturally "Mohammedan" Balkan area was a warning example of what would happen, particularly in Western Europe, if the European and Asian combined. By exaggerating differences, the image created of the Balkans was at the same time probably used as a dark point of comparison against which one's own advancement and cultural virtues seemed brighter and more desirable.

\section{A step in a more positive direction: changes in image from the 1920s to the 1960s \\ When Finland separated from Russia, changes, particularly in history and geography education, took place. In geography, independent Finland gained an even more pronounced status in education when focus on the (former) Russian Empire decreased substantially. History could be taught in}

\footnotetext{
31 Aro \& Rosberg 1908, 176-177; Jotuni 1916, 108; Kanninen 1895, 64; Lagerblad 1890, 150; Modeen 1886, 141-142.

32 Hainari 1911, 9-23 (144); Melander 1875, 10-25 (150); Wallin 1898, 13-30 (103); Wichmann \& Rihtniemi 1914, 12-25, 181-182 (190). The number in brackets displays the number of pages that was dedicated to the history of the world as a whole.

33 Aro \& Rosberg 1908, 176; Forsström 1898, 125; Lagerblad 1890, 151; Modeen 1886, 139.
} 
a more nationalistic vein when the interpretations and interests of Russia did not have to be taken into account anymore. These factors contributed to the fact that in the 1920s completely new history and geography textbooks were taken into use in Finland while old ones were updated in many respects. These new books (that might be considered the second generation in the context of this study) served in schools with minor changes until the 1950s, or even the 1960s.

The content of schoolbooks was directed by committee reports during the years 1925, 1933 and 1946, which made recommendations regarding the teaching of all subjects as had occurred in 1899. The basic starting points of the new guidelines were very similar to those in 1899 . School children were to be brought up in Christianity and moral thought that was based on this. Central in history were "history of the fatherland" and in geography, "geography of the fatherland". ${ }^{34}$ Of objectives regarding the presentation of the rest of the world, the guidelines of 1925 stated the following: "[I]t must be shown how our country offers its own advantages and opportunities, which should not be looked down on alongside the rest of the world, when we are able to use them effectively in the same way as foreigners" ${ }^{35}$ The portrayal of other countries could fulfill these kinds of goals in two ways, by presenting either encouraging or warning examples from the world.

However, the aforementioned trends did not significantly affect the way the Balkans was presented. The contents of this portrayal and its quality essentially remained the same from the 1920s to the 1950s, and only minor changes took place. First, it can be noted that in history as well as geography textbooks, stereotypes about unrest in the Balkans and about the overall belligerence of its people was strongest during this period. ${ }^{36}$ The Balkan wars and the First World War were fresh in memories, and the next world war had not yet left them in its shade. The Second World War came to dominate recent history in textbooks only at the beginning of the 1960s, when

\footnotetext{
34 Maalaiskansakoulun opetussuunnitelma. Komiteamietintö (Helsinki: Valtioneuvosto, 1925), 108113, 140-146; Oppikoulukomitean mietintö (Helsinki: Valtioneuvosto, 1933), 319; Kansakoulun opetussuunnitelmakomitean mietintö I (Helsinki: Valtioneuvosto, 1946), 8.

${ }_{35}$ Maalaiskansakoulun opetussuunnitelma 1925, 52, 149-150.

36 J. E. Aro \& J. E. Rosberg, Koulun maantieto (Helsinki: Otava, 1923), 151, 154; Väino Auer \& K. Merikoski, Maantieto (Helsinki: Otava, 1938), 180, 182; Alfred Jotuni, Kansakoulun maantiede (Porvoo: WSOY, 1924), 113-114; Sigurd Sahlberg, Lärobok i geografi II (Nykarleby: Författarens förlag, 1931), 78-79. 
textbooks from the interwar period were finally put out of use, becoming pedagogically obsolete in their content.

In history textbooks, from the 1920s to the 1950s the Balkan area was presented as a detail relating to the First World War. The role and objectives of Balkan countries in the world war were not addressed in a single Finnish schoolbook. ${ }^{37}$ The same was true of events of the later Second World War. The Balkans were mentioned only as an area where the German attack was centered in the spring of 1941, but this sequence of events was not considered to be significant enough in the context of the war that it could be commented on further. ${ }^{38}$

In geography textbooks as a whole, there was nevertheless a step towards a more positive portrayal of other cultures and countries. Although Christianity was still seen as the "right" faith, other faiths were no longer criticised in the form of the previous decades. In the case of the Balkans, criticism of the "national character" and customs of Muslims that were perceived to be alien also lessened. Cultural differences were presented, but for the most part in a neutral tone. ${ }^{39}$ On the other hand, a few books continuously argued that the Albanians, in particular, were half wild and that the European side of Turkey, for instance Constantinople, was extremely dirty and noisy. 40 Thus, the foreignness and difference of the Balkans was focused more than previously on the Islamic areas of the region and on minorities, while the Christian areas and peoples received some positive attention.

A few authors, however, still depicted the area in the traditional negative way. For instance, in Elementary School Geography by A. Jotuni (Kansakoulun maantiede) the Balkans were portrayed in the following way in 1924:

"The Balkan Peninsula has been named 'the restless corner of Europe' for the reason that the states in this area have continuously been in arms

\footnotetext{
37 The First World War in history textbooks: see, for instance, O. A. Hainari \& A. V. Laitakari, Kansakoulun historian oppikirja (Jyväskylä: Gummerus, 1926), 239-46; Hästesko 1931, 210-226; Juva et al. 1938, 216-225; Mantere \& Sarva 1926, 314-325; Ora \& Ottelin 1946, 220-231.

38 Kuusi \& Elimäki 1951, 298; Mantere \& Sarva 1961, 352-355.

39 A. Hakalehto \& A. Salmela, Isänmaa ja maailma. Kansakoulun maantieto (Porvoo: WSOY, 1931), 202-203; I. Leiviskä, Kansakoulun maantieto 1 (Helsinki: Maalaiskuntien liitto, 1926), 123 125; Viljo Tolvanen, Kansakoulun maantieto I (Helsinki: Otava, 1927), 167-175.

40 Aro \& Rosberg 1923, 156; Jotuni 1924, 114-116; Sahlberg 1931, 79.
} 
against each other. New states have now and then been born and previous ones have disappeared. Order has been poor, and security has been lacking [---] The South Slavic peoples are relatives to the Eastern Slaves in the respect that the education of the people has been neglected. Half of the population is illiterate and behind in every way [---] Constantinople is considered to be a semi-sacred city. But the streets are narrow and dirty. Food leftovers and other dirt are thrown onto them. When vendors call out and the city's many dogs bark, there is a deafening hubbub on the streets." 41

Bulgaria, Greece and Yugoslavia were still described as relatively poor and underdeveloped, but in the case of these countries it was often mentioned that things had improved slightly for the better..$^{42}$ Diligence, spirit of enterprise and effort to improve educational and economic level were things that could be recognized, from the perspective of Finnish writers. Thus, some areas of the Balkans were probably meant to be used as a positive example for Finnish schoolchildren that illustrated that it was indeed possible to develop one's own country and people regardless of poor natural resources and harsh climate. On the other hand, in the case of Greece, a few books mentioned that the country had declined in comparison to ancient times, when Greece had been the leading state of Europe. ${ }^{43}$ Perhaps such comments were a reflection of the decreasing admiration of ancient times within Finnish scientific circles. Ancient achievements at least were not considered to have the same value as they did in the late 1800 s and early 1900s. Instead, it was considered that all peoples and countries had to work with renewed energy for the good of present society and to create a brighter future.

Until the 1950s, schoolbooks emphasized text, and there was little illustration, hardly at all during the 1800s. The development of printing technology gradually changed this situation. At the beginning of the 1900s, there were generally one or two pictures in textbooks relating to the Balkans. Of the pictures, one generally illustrated the mountainous environment (Ill. 1) or Constantinople with its "Eastern" minarets (Ill. 2) and the other, rural folk dressed in national costume from a Balkan country (Ill. 3). The modern

\footnotetext{
41 Jotuni 1924, 113-116.

42 Aro \& Rosberg 1923, 152-157; Jotuni 1924, 113-115; Sahlberg 1931, 79-80; Tolvanen 1927, 167171.

43 Hakalehto \& Salmela 1931, 203; Tolvanen 1927, 172. 
side of society was not portrayed at all. It is apparent that the visual pictures supported the images created by the text. Something "typical" wanted to be presented of the Balkans, which in practice meant that images that were as culturally and geographically exotic as possible in Finnish eyes were chosen. In other words, when the Balkans were perceived as "different", there was either a conscious or unconscious choice to select pictures in which people and nature certainly looked different from in one's homeland, strengthening presumptions. This kind of tendency in selection was a phenomenon that generally occured elsewhere, too, in the period in question and not only in Finland. ${ }^{44}$

Ill. , 1 Mountains in Sparta (Source: Sahlberg 1931, 78)

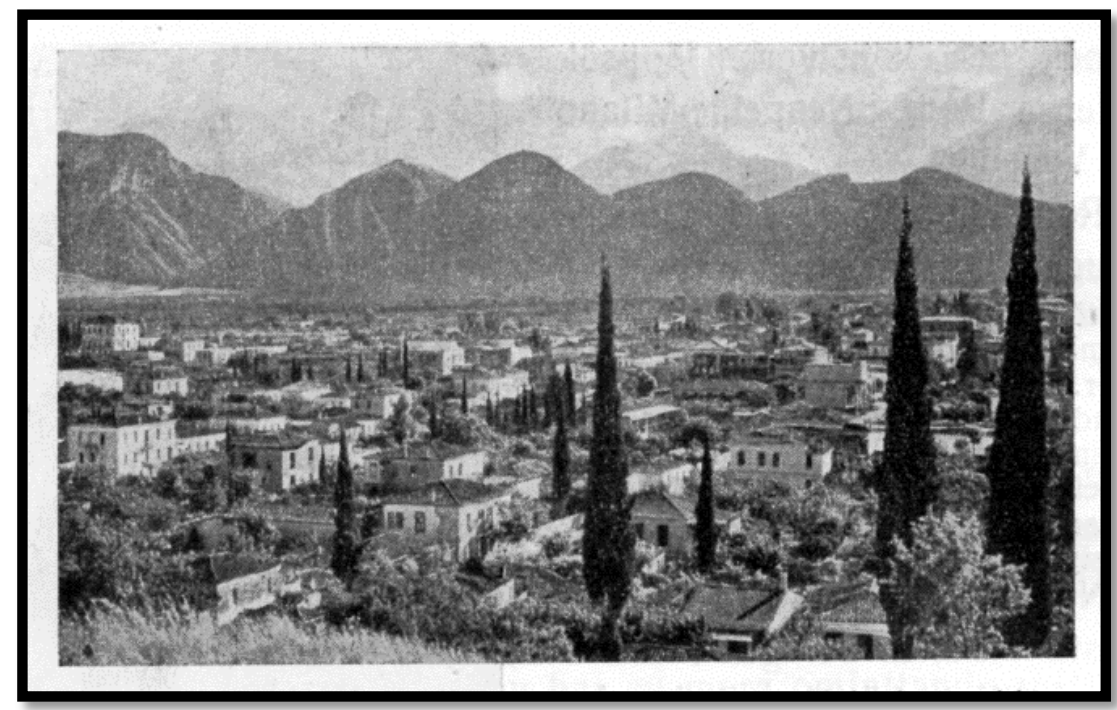

44 Cf. Hemminki 2005, 23-26, 40-43, 60-61; Kukkonen 2003, 25; Rantahäli 2003, 13-19. 
Ill. 2 Hagia Sofia, Constanople (Source: Leiviskä 1926, 125)

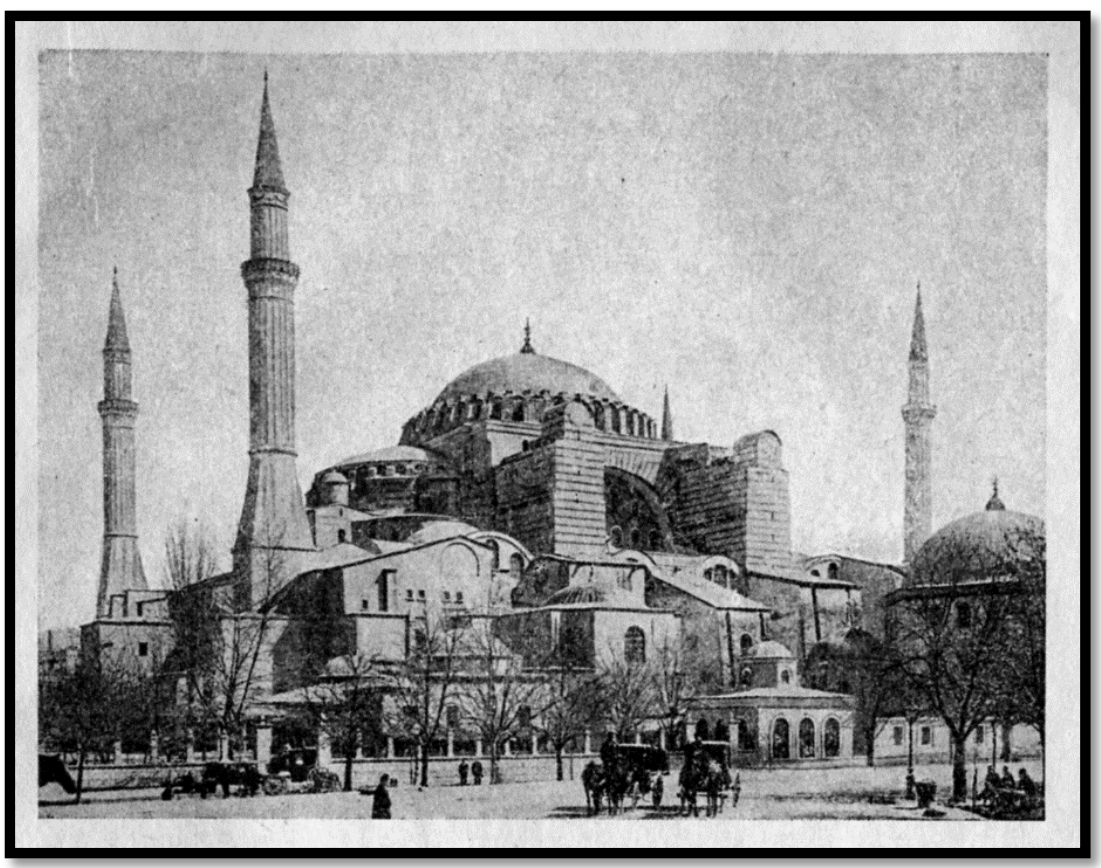

Ill. 3 Greek girl in national costume (Source: Leiviskä 1926, 124)

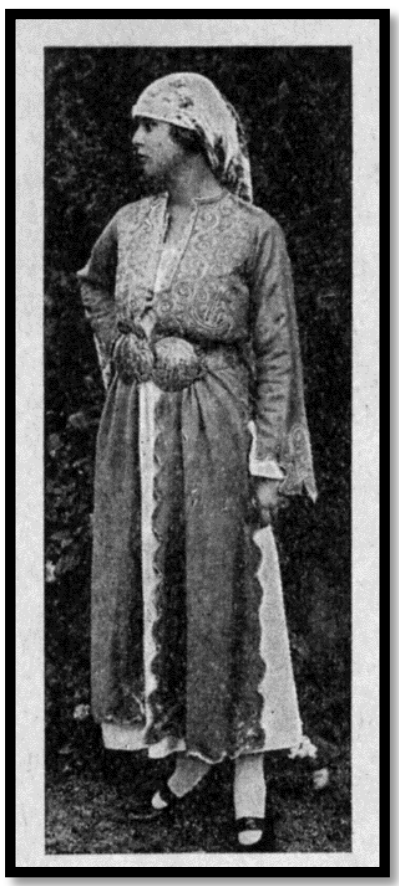


As a whole, the description conveyed of the Balkans in Finnish schoolbooks even in the 1950s was related to a strong belief in the superiority of "western culture", which was a prevailing attitude in other areas besides western countries. In practice, "western culture" was mostly considered to include the Romanic and Germanic language areas of Europe as well as culture in the Anglo-American sphere. It was not taken for granted that Finland belonged to this sphere, but Finland was preferably seen to be a western country due to its level of education and social features. ${ }^{45}$ From the 1920s to 1950's, the Balkans appeared in a similar dual role. On one hand, the Christian or "European" parts of the Balkans were separated more clearly in schoolbooks, where signs of improvement were seen. On the other, the Islamic or "Eastern" areas and their cultural and social features were still seen as alien and inferior and were rejected. The cultural relativism that gradually gained support in the western countries thus had a small influence in descriptions, as the sharpest criticism and disparagement were left out of schoolbooks in the interwar period. However, in books used until the 1950s the Balkans was substantially described in the same manner as they were in the 1800s.

\section{From a backwards Balkans to neutral Eastern and South- Eastern Europe: imagery in schoolbooks from the 1960s to the 1980s \\ During the 1960s, there was a significant change in Western} European attitudes towards other cultures, at least on a public level and on the level of recommendations. Other cultures began to be interpreted as equal with Western culture, and in school education, for instance, instilling understanding and toleration of difference in children became a goal. The content of Finnish schoolbooks was changed in line with these ideals. New national guidelines were drawn up and supplemented several times between the years 1964 and 1985.46 The books that were created in the context of this reform can be considered the third generation of Finnish schoolbooks.

\footnotetext{
45 Cf. Vesa Vares, '"Never satisfactory, according to the Finnish standards". From optimism and interest to disappointment and disillusion: Finnish views on the nations in Eastern Central Europe between the world wars', The Romanian Journal for Baltic and Nordic Studies, Vol. 3, Issue 2 (2011): 229, 234-238, 243-244.

46 Kunnallisten kokeilukoulujen opetussuunnitelmakomitean mietintö (Helsinki: Valtioneuvosto, 1965), 67; Peruskoulun opetussuunnitelmakomitean mietintö II (Helsinki: Valtioneuvosto, 1970), 216; Lukion opetussuunnitelmakomitean mietintö 2 D (Helsinki: Valtioneuvosto, 1977), 828, 840; Peruskoulun opetussuunnitelman perusteet 1985, 170.
} 
The change had a clear impact on the way the Balkans was described in Finnish school textbooks from the 1960s to the 1980s. In addition, the political effects of the Cold War were apparent in the content of schoolbooks in relation to the Balkans.

One significant change was that the entire concept of the Balkans was eliminated from Finnish schoolbooks. During the Cold War, when Europe was conceptually split in two, into socialist Eastern Europe and non-socialist Western Europe, this imagery did not leave room for "the Balkans" as a separate regional or cultural term. In a political sense, Greece and Turkey belonged to the west, while Bulgaria, Albania and Yugoslavia belonged to the east. A few schoolbooks mentioned the Balkan Peninsula in the context of natural geography, ${ }^{47}$ but the term was not used in the context of presenting the societies. Bulgaria, Albania and Yugoslavia, as well as Romania, which was now attached to them, were considered to belong to Eastern Europe or Southeastern Europe, which was part of the political Eastern Europe. Similarly, Hungary, Czechoslovakia and Poland, northern socialist countries, constituted the central part of Eastern Europe in this context. ${ }^{48}$

The educational planning committee report of 1970 which set out broad reforms in education strongly emphasized that in the case of Europe - but quite revealingly no other parts of the world - that "There cannot be any simplified or negative views on any country or people" ${ }^{49}$ (italics in original). The emphasis of this perspective was likely related to the political balancing act of the Cold War. The political administration directing school education probably wanted to make sure that schoolbooks should not include anything that could be interpreted as a criticism of socialist ideology or socialist countries, especially the Soviet Union. The Soviet Union was in fact very keen in responding to any "anti-Soviet" phenomena that it interpreted in Finland.50 In principle, these guidelines also prevented the criticism of "capitalist" countries, but criticisms in the direction of the West generally

\footnotetext{
47 Vesa Koivisto et al., Omasta maasta maailmalle 5 (Espoo: Weilin + Göös, 1986), 10-12; Matti Leinonen et al., Koulun maantieto 5 (Helsinki: Otava, 1984), 68.

48 Harry Krogerus \& Lennart Winqvist, Vår värld åk $5 b$ (Borgå: Söderström et C:o, 1976), 31-51; Leinonen 1984, 60-69; Oiva Louhisola \& Paavo Kuosmanen, Omasta maasta maailmalle (Helsinki: Valistus, 1958), 47-79. See also Todorova 2009, 140-147.

${ }^{49}$ Peruskoulun opetussuunnitelmakomitean mietintö 1970, 199.

50 'Juri Derjabin: Puhe Suomen ja Neuvostoliiton ystävyydestä oli liturgiaa', Helsingin Sanomat 28.10.2012.
} 
did not result in any foreign policy problems. Therefore, these guidelines must be interpreted as existing to pressure writers to avoid the negative characterization of socialist systems.

The general objective of tolerance as well as political prudence changed the imagery of Finnish schoolbooks in regard to the Balkan countries to one that was first neutral ${ }^{51}$ and later positive beginning from the 1960s. The books provided the basics on the economy, culture, and social system of Balkan countries without commenting on any problems in any area of life. On the contrary, every now and then the books made reference to the rapid development of the countries and future opportunities. ${ }^{52}$ At the same time, problems in Western Europe were mentioned, such as environmental problems (erosion, pollution), differences in development between the countries, such as the poverty of Portugal and Southern Italy, and even political conflicts (the Basques). ${ }^{53}$ This kind of "one-sided equality" was no doubt the result of the aforementioned political directive. ${ }^{54}$

For instance, in the textbook "Learn Geography," (1981) Bulgaria was portrayed very positively:

\begin{abstract}
"There are plenty of tomatoes, peppers, tobacco, grapes and wine to export. The potato crop is generally ready before the crop in central Europe, so there are lots of eager buyers [---] One specialty is the cultivation of roses. Bulgaria produces the largest amount of rose oil in the world. [---] With the support of these (CMEA) countries, Bulgaria is rapidly industrializing. There is an incoming oil pipeline from the Soviet Union, but there are also energy resources, mainly lignite." 55
\end{abstract}

The number of photos in schoolbooks increased sharply in the 1970s and 1980s. The photo selection supported the image portrayed of the Balkans: they mostly portrayed major cities (Ill. 4), industrial plants (Ill. 5), and grain harvesting or rose oil production (Ill. 6). A few pictures still presented people dressed in national costume and even horse-drawn

\footnotetext{
51 Väinö Auer \& K. Merikoski, Maantieto kansakouluja varten (Helsinki: Otava, 1951), 204-208; Iivari Leiviskä, Koulun maantieto (Porvoo: WSOY, 1956), 202-209; Louhisola \& Kuosmanen 1958, 225-234.

52 Krogerus \& Winqvist 1976), 47-51; Jorma Kytömäki et al., Opi maantietoa 5 (Porvoo: WSOY, 1981), 100-107; Leinonen et al. 1984, 67-69.

53 Kytömäki et al. 1981, 75, 78, 88-90; Leinonen et al. 1984, 96-97, 103, 110.

54 Cf. Holmén 2006, 319-322.

55 Kytömäki et al. 1981, 102-104.
} 
carriages (Ill. 7), but the latter case stressed that they were "memories, as if from the past". 56 Thus, readers were given to understand that these kinds of exotic things were not in any way in conflict with the construction of a modern socialist society. Exotic landscapes and national costumes still reflected the cultural difference of the Balkans in comparison to Finland from the 1960s to the 1980s, but otherwise, the image conveyed by books emphasized the modernity and prosperity of the countries. In this sense, at the end of the Cold War, the "South Eastern European countries" were presented as being roughly equal with Finland.

Ill. 4 Bucharest Palace of Culture and Science, (Source: Leinonen et al. 1984, 68)

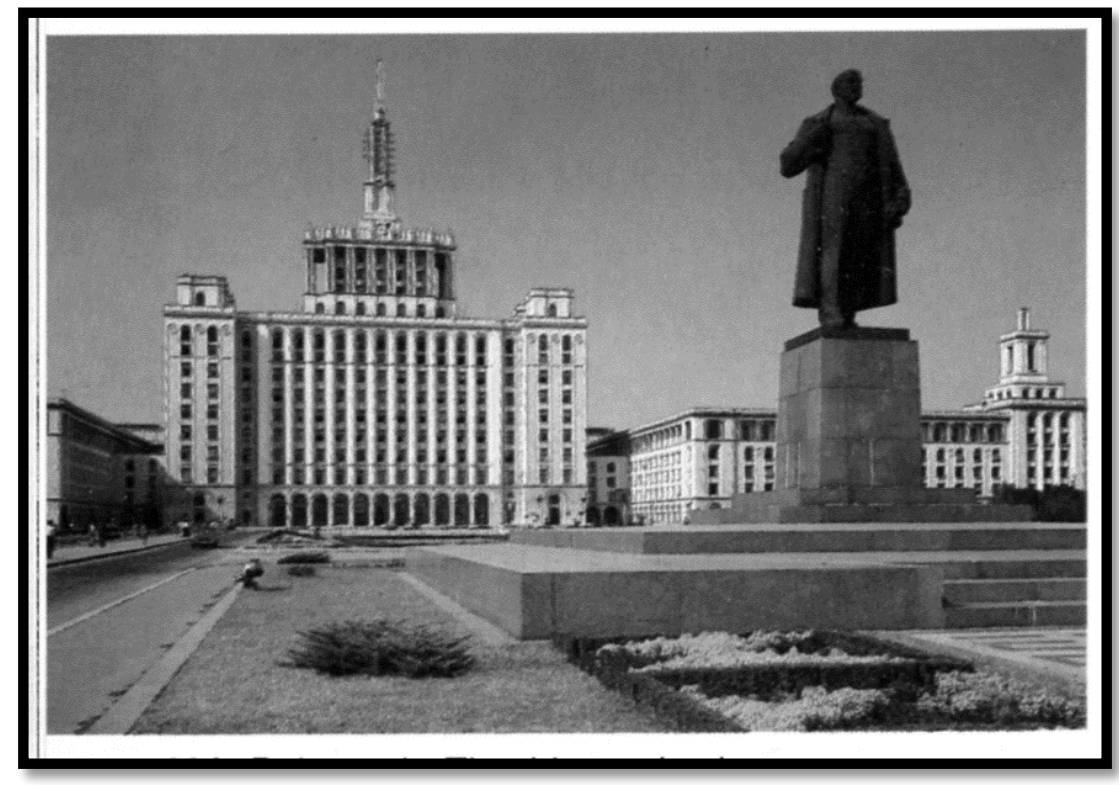

56 Kytömäki et al. 1981, 101. See also Leinonen et al. 1984, 68-69. 
Ill. 5 Romanian industry (Source: Kytömäki et al. 1981, 108)

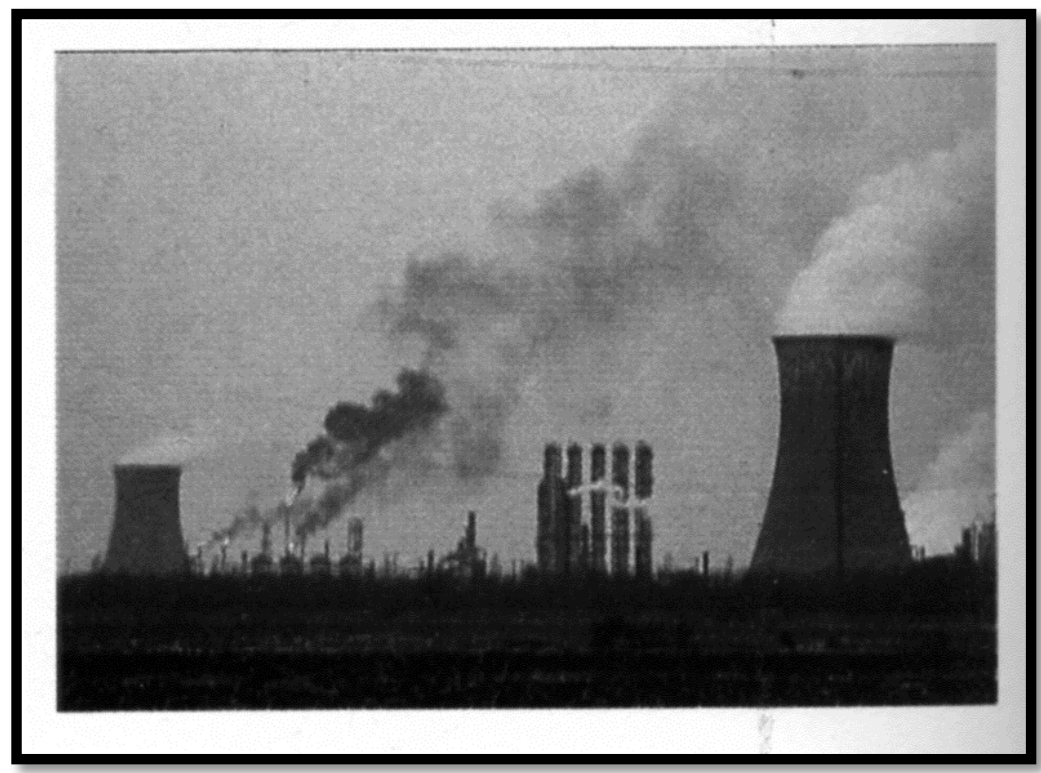

Ill. 6 Rose oil production in Bulgaria (Source: Kytömäki et al. 1981, 103)

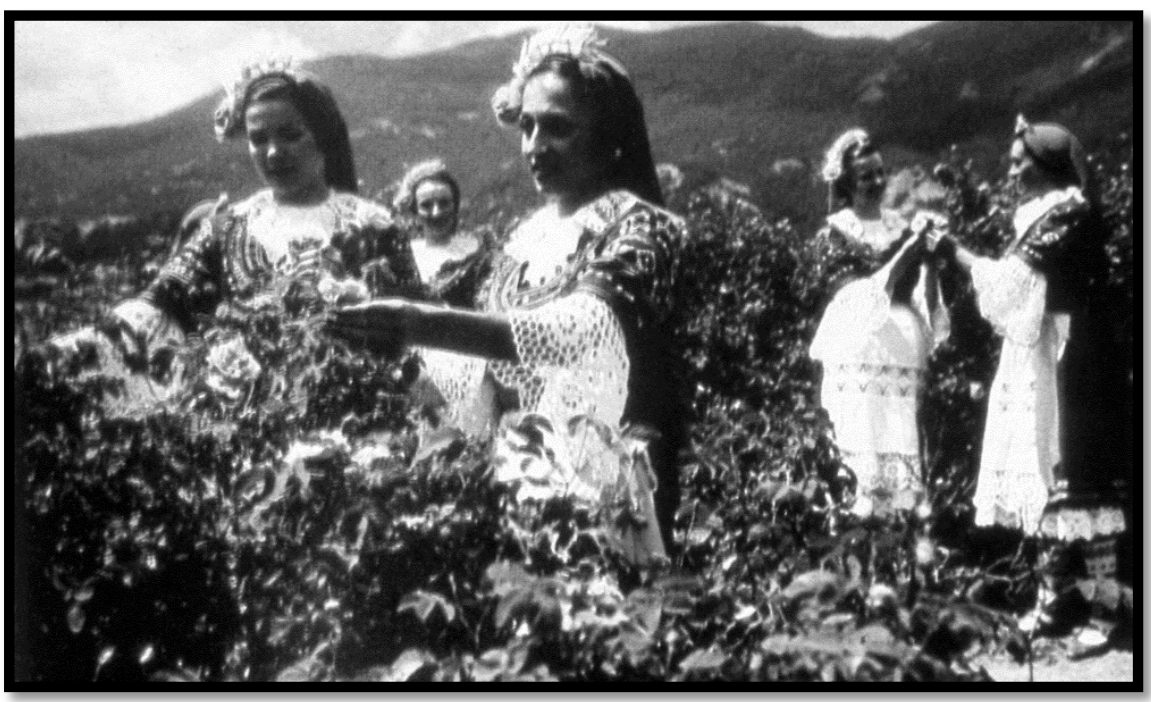


Ill. 7 Horse-drawn carriages (Source: Leinonen et al. 1984, 69)

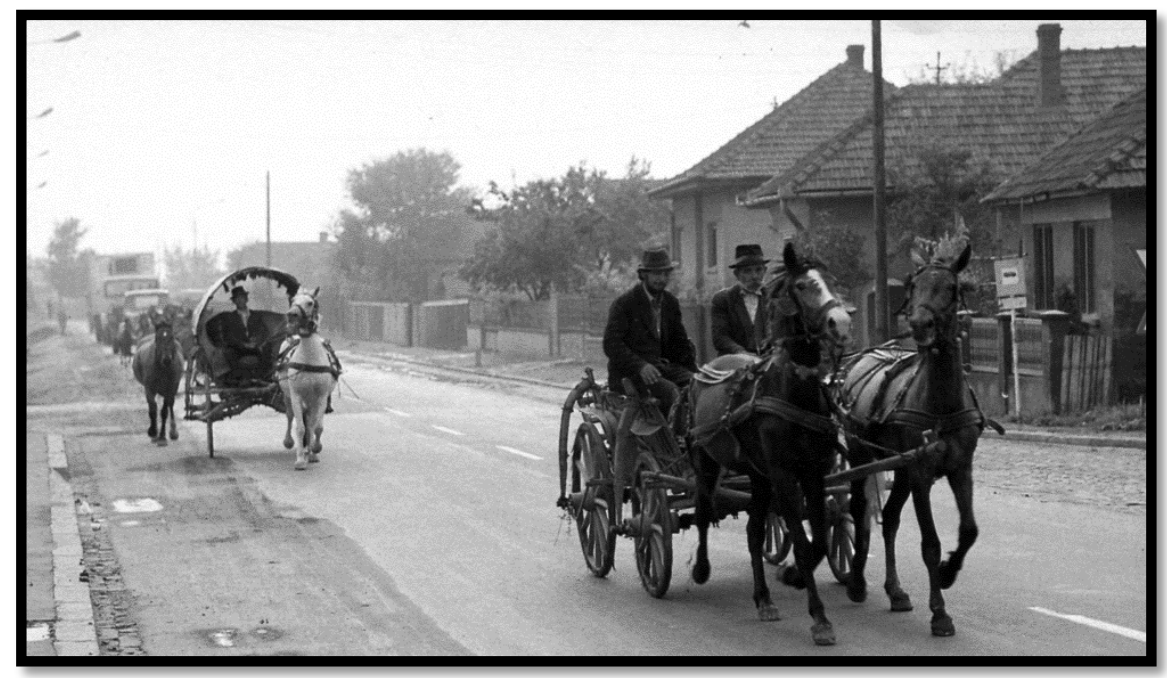

The return of the problematic Balkans: imagery in schoolbooks during the 1990s and 2000s

The books that were created in the late 1960s and in the beginning of the 1970s, as the Finnish comprehensive school system was reformed significantly, were predominant until around the early 1990s. After that a new (in this context the fourth) generation of schoolbooks has been born, due to diverse political, societal and mental changes.

During the last two decades, the showcasing of values based on the the United Nations Declaration of Human Rights have gained a strong position in education in Finland and in many other countries. The objective has been that schoolchildren would be instilled from an early age to actively support internationalization, multiculturalism and the acceptance of diversity. In the case of geography, this has even meant that the special status of one's own country, people and culture has been left out of the curriculum. Instead, emphasis has been put on respecting and appreciating (not only understanding and tolerating) other cultures. ${ }^{57}$ These trends have in principle created favorable conditions in that the neutral or positive portrayal of the Balkans from the 1960s to the 1980s could have strengthened in a still more positive direction.

57 Peruskoulun opetussuunnitelman perusteet (Helsinki: Opetushallitus, 1994), 8-14, 96; Perusopetuksen opetussuunnitelman perusteet (Helsinki: Opetushallitus, 2004), 12, 36-37, 174. 
However, in the case of Southeastern Europe, cosmopolitan ideals have been left in the shade of a strong counterforce. The Yugoslav Wars widely shocked people outside the country, too, which have again brought to the fore the mostly forgotten stereotype of the Balkans as a nest of unrest and violence. ${ }^{58}$ The end of the Cold War has meant a freed atmosphere of dialogue, including that in schoolbooks. During the 1990s there has been more courage in abandoning a neutral stance towards and discussion of problems in former socialist countries. During the last two decades, Finnish schoolbooks have portrayed the Balkans in a partly realistic vein, yet partly in the light of old negative simplifications.

First, "the return to the old" has meant the reintroduction of the term Balkan. In the 1990s and 2000s, most schoolbooks have used the term along with "Southeast Europe." At the same time, the term has been expanded to include Romania, which has apparently been viewed as being more similar to the Balkan Peninsula than the Central Eastern European countries. The term Balkan has also been used to describe the basic nature of all of the states. The Yugoslav Wars have been called the "Balkan" wars, and all of the states in the region have been referred to as "the Balkans, which have experienced hardship". The latter has referred to the socialist past of the countries, of which the adverse effects have been brought up openly but with exaggeration. For instance, the low standard of living and social problems have appeared to be the result of the recent past in schoolbooks. ${ }^{59}$

Schoolbooks have drawn special attention to the ethnic diversity of Balkan countries. The Balkans has been portrayed as a "mosaic" of nationalities in which the residential areas of various peoples do not form clear entities. This in turn has led to border disputes that are difficult to solve and other problems which are caused by the coordination of different

\footnotetext{
58 Cf. Todorova 2009, 4-7, 136-139; Ivana Živančević-Sekeruš, "Balkans," in Imagology. The cultural construction and literary representation of national characters. A critical survey, ed. by Manfred Beller and Joep Leerssen (Amsterdam: Rodopi, 2007), 107.

${ }_{59}$ Marketta Ahtiainen et al., Kansainvälisten suhteiden aikakirja (Helsinki: Edita, 2003), 141-142; Jukka Arohonka et al., Värikäs Eurooppa (Helsinki: WSOY, 1997), 99-102; Pauli Arola et al., Kronos 3. Kansainväliset suhteet (Helsinki: Kirjayhtymä, 1995), 115; Hannele Cantell et al., Matkalle Eurooppaan (Helsinki: WSOY, 2002), 137-143; Jouni Ekonen et al., Ihmisen tiet. Kansainväliset suhteet (Helsinki: Otava, 1995), 151-153; Rita Keskitalo et al., Avara Eurooppa (Helsinki: WSOYpro OY, 2010), 98-103; Matti Leinonen et al., KM Eurooppa (Helsinki: Otava 2007), 115-116.
} 
interests..$^{60}$ The image is of course based on reality, but it has once again been exaggerated and is questionable. In addition, all Southeast European countries have been bundled under this kind of problematic description without any kind of discussion as to the differences between different countries in Finnish schoolbooks. In addition, the general tone of negativity in imagery is pronounced when comparisons are made to the way in which Western European multiculturalism is portrayed. Apparently, in the name of political correctness, conflicts that have been the result of cultural encounters between "original" population and immigrants (from Islamic countries in particular) in Western Europe have not been portrayed in the same way. ${ }^{6}$

At the very least, the difference has been the fact that in portrayals of Western Europe, ethnic diversity has not been presented as a problem, and critical views have not been said to concern ordinary people. In the case of Western Europe, problems have partly been "outsourced" as being the responsibility of fringe extremist groups: for instance, in the case of Germany, neo-Nazis are mentioned as being hostile towards immigrants, while "ordinary people" are said to be supporters of multiculturalism. ${ }^{62} \mathrm{In}$ Finnish schoolbooks, in the case of the Balkans, a similar type of differentiation between "extremists" and "the tolerant general majority," have not been made, but it has been given to understand that ethnic conflicts are an inseparable and eternal part of life in the Balkans.

For instance, in the geography textbook A Trip to Europe, (Matkalle Eurooppaan, 2001) the Balkans are portrayed as follows:

"The Catholic religion from Rome, Orthodox from Bysantine, Islamic from Istanbul, the Latin alphabet, the Cyrillic alphabet, Slavic languages, a drop of Romanian, Turkish and Albanian. Mix for a thousand years. There it is: The Balkans. Key words:

\footnotetext{
60 Arohonka et al. 1997, 99-102; Cantell et al. 2002, 136-143; Keskitalo et al. 2010, 104-109; Leinonen et al. 2007, 76-78.

61 Arola et al. 1995, 149-51; Cantell et al. 2002, 47; Keskitalo et al. 2010, 44-47; Leinonen et al. 2007, 12.

62 Ahtiainen et. al. 2003, 143; Cantell et al. 2002, 103; Ekonen et al. 1995, 153; Esko Heikkonen et al., Muutosten maailma. Kansainväliset suhteet (Helsinki: WSOY, 2009), 150; Leinonen et al. 2007,100 . 
karst formations, cultural differences, ethnic group[s], civil war." 63

In the case of the newest generation of Finnish schoolbooks also, textual and visual depictions have been in conformity: the latter have supported the image conveyed by the former. Illustrations of exotic landscapes (for instance, karst formations, Ill. 8) and "old-fashioned" countryside or national costumes (Ill. 9) have reflected the cultural difference of the Balkans in comparison to Finland in the post-Cold war period, as they had done already in the interwar period.

Ill. 8 Cross-section of a karst formation (Source: Arohonka et al. 1997, 100)

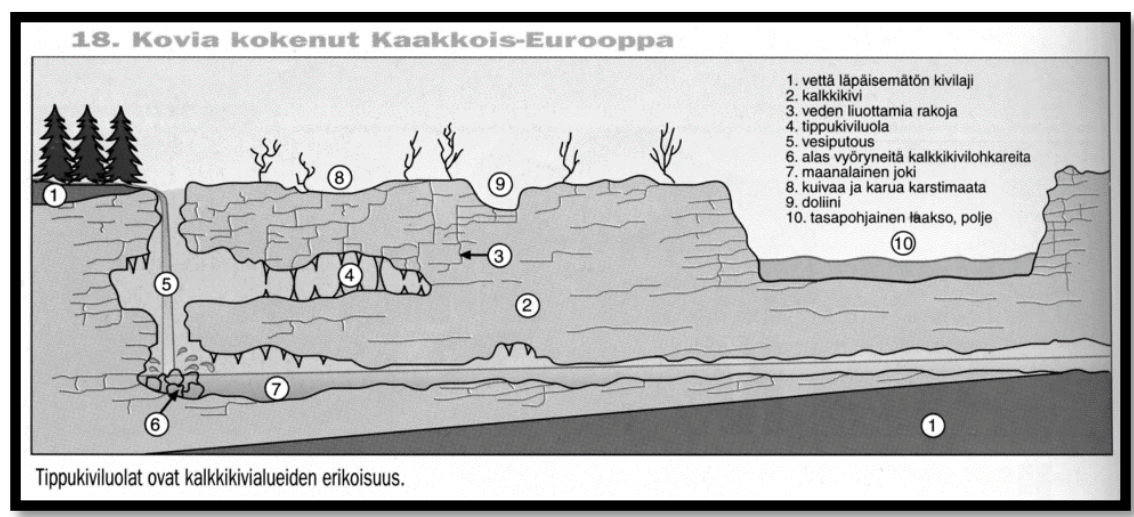

Ill. 9 Roma brothers from the Balkans (Source: Arohonka et al. 1997, 101)

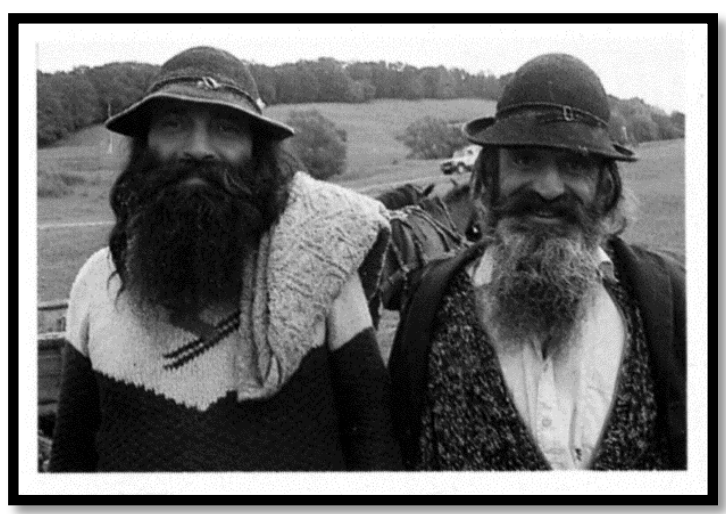

63 Cantell et al. 2002, 136. 
Thus, during the 1990s and 2000s the image of the Balkans in Finnish schoolbooks has separated substantially from the neutrality of the 1960s to 1980s and begun to resemble that image that was predominant from the 1920s to 1950s. Unrest, a harmful ethnic and cultural diversity, poverty and underdevelopment have been the key elements of the image. The fact that the image portrayed in schoolbooks has been in clear conflict with the formal objectives of education says much about the strength of old stereotypes. As recent events in the Balkans, particularly the Yugoslav Wars, have created favourable conditions for the rise of old, simplified and largely negative images, this has occured, although the general guidelines given to textbook writers regarding the portrayal of other states, peoples and cultures has been almost the opposite. Based on schoolbooks at least, "respect and appreciation" for the special cultural and social features of the Balkan area has not been achieved.

\section{Conclusions}

The broad trends relating to politics and educational priorities have to some extent affected the way how the Balkan area has been depicted in Finnish schoolbooks. However, it can be concluded that the image of the Balkan area conveyed by Finnish schoolbooks has not fundamentally changed during the modern school system from the late $19^{\text {th }}$ century onwards. The whole time, the image has been based on a limited number of simplifications and stereotypic perceptions. As such the image could be described as a "map in the mind" that depicts and more or less reflects reality but is not itself real. The image always contains descriptive and value-added elements.

When the image of the Balkans transmitted by Finnish schoolbooks is compared with other Finnish perceptions of the area considerable similarities can be seen. Finnish travel literature as well as diplomatic reports in the interwar period largely reflected the same cultural and national stereotypes, often with an emphasis on "Easternness" and "underdevelopment". At the same time, Finnish schoolbooks to a great extent reflected the image of the Balkan area that was prevalent in Western and Northern Europe, without any special Finnish features. Comparison with other studies that deal with the worldview of Finnish schoolbooks also reveal that smaller changes in description concerning the Balkan area have 
progressed at the same pace as changes in image concerning other areas, such as India, China, or the United States.

For its part, this study confirms the interpretation according to which mental images are durable and long-lasting, and in most cases, they tend to be unfavorable ones. The overwhelmingly negative image that was created of the Balkans and further strengthened by exaggerating differences was probably used as a comparison against which one's own advancement and cultural virtues in Finland seemed brighter and even more desirable. It is possible to agree with Vesa Vares, for instance, who has argued that the image created of the Balkan area was a part of the Finnish identity-building process. Here, the Balkans, like the East Central Europe in general, served as a reference group to which the Finns did not want to belong. In the eyes of the Finns, the Balkans was inferior and a representative of "Otherness" while Scandinavian countries and Western Europe were admired and set as a positive reference group.

All in all, the image created of the Balkans in Finnish schoolbooks, as it has been for about the last 140 years, can be considered a typical example of mental region-building. It may be rightly argued that regions are never pre-given or ontologically unproblematic, but they are always discursively constructed and results of conscious and unconscious mental processes including the selection of information, stereotypes, beliefs, attitudes, opinions, myths, hopes, fears and similar emotions. Nevertheless, the effects of mental region-building are real, as people tend to believe that their views reflect reality. The simplification "Once Balkans, always Balkans" with a wide range of beliefs and emotions connected to it has proven to be reluctant to change and has also the possibility to remarkably affect the relations between Finland and the Balkan area. 


\section{References:}

\section{A. Schoolbooks and other primary sources}

Ahonen, Sirkka et al. Koulun historia 8. Helsinki: Otava, 1987.

Ahtiainen, Marketta et al. Kansainvälisten suhteiden aikakirja. Helsinki: Edita, 2003.

Aro, J. E. \& Rosberg, J. E. Koulun maantieto. Helsinki: Otava, 1908.

Aro, J. E. \& Rosberg, J. E. Koulun maantieto. Helsinki: Otava, 1923.

Arohonka, Jukka et al. Värikäs Eurooppa. Helsinki: WSOY, 1997.

Arola, Pauli et al. Kronos 3. Kansainväliset suhteet. Helsinki: Kirjayhtymä, 1995.

Auer, Väino \& Merikoski, K. Maantieto. Helsinki: Otava, 1938.

Auer, Väinö \& Merikoski, K. Maantieto kansakouluja varten. Helsinki: Otava, 1951.

Cantell, Hannele et al. Matkalle Eurooppaan. Helsinki: WSOY, 2002.

Ekonen, Jouni et al. Ihmisen tiet. Kansainväliset suhteet. Helsinki: Otava, 1995.

Erslev, Ed. Lärobok i geografin. Wiborg: Clouberg, 1882.

Forsström, O. A. Kansakoulun maantieto. Helsinki: Weilin \& Göös, 1901.

Hainari, O. A. \& Laitakari, A. V. Kansakoulun historian oppikirja. Jyväskylä: Gummerus, 1926.

Hainari, O. A. Yleisen historian oppikirja kansakouluja varten. Jyväskylä: Gummerus, 1911.

Hakalehto, A. \& Salmela, A. Isänmaa ja maailma. Porvoo: WSOY, 1931.

Heikkonen, Esko et al. Muutosten maailma. Kansainväliset suhteet. Helsinki: WSOY, 2009.

Hästesko, F. A. Historian oppikirja kansakouluja varten. Porvoo: WSOY, 1931.

Jotuni, Alfred. Kansakoulun maantiede. Porvoo: WSOY, 1916.

Jotuni, Alfred. Kansakoulun maantiede. Porvoo: WSOY, 1924.

Juva, Einar W. et al. Isänmaan historia. Helsinki: Otava, 1938.

Kanninen, August. Kansakoulun maantieto. Tampere: H. T. Bärlund, 1895.

Kansakoulun opetussuunnitelmakomitean mietintö I. Helsinki: Valtioneuvosto, 1946.

Keskitalo, Rita et al. Avara Eurooppa. Helsinki: WSOYpro OY, 2010.

Koivisto, Vesa et al. Omasta maasta maailmalle 5. Espoo: Weilin + Göös, 1986.

Krogerus, Harry \& Winqvist, Lennart. Vår värld åk $5 b$. Borgå: Söderström et C:o, 1976. 
Kunnallisten kokeilukoulujen opetussuunnitelmakomitean mietintö. Helsinki: Valtioneuvosto, 1965.

Kuusi, Sakari \& Elimäki, Lauri. Kansakoulun historian oppikirja. Jyväskylä: Gummerus, 1951.

Kytömäki, Jorma et al. Opi maantietoa 5. Porvoo: WSOY, 1981.

Lagerblad, Elis. Lärobok i geografi. Borgå: Werner Söderström, 1890.

Lappalainen, Osmo et al. Horisontti. Historia Napoleonista nykypäivään. Helsinki: Otava, 1998.

Leinonen, Matti et al. KM Eurooppa. Helsinki: Otava 2007.

Leinonen, Matti et al. Koulun maantieto 5. Helsinki: Otava, 1984.

Leiviskä, I. Kansakoulun maantieto I. Helsinki: Maalaiskuntien liitto, 1926.

Leiviskä, Iivari. Koulun maantieto. Porvoo: WSOY, 1956.

Lindeqvist, K. O. Uuden ajan historian oppikirja. Porvoo: WSOY, 1913.

Louhisola, Oiva \& Kuosmanen, Paavo. Omasta maasta maailmalle. Helsinki: Valistus, 1958.

Lukion opetussuunnitelmakomitean mietintö 2 D. Helsinki: Valtioneuvosto, 1977.

Maalaiskansakoulun opetussuunnitelma. Komiteamietintö. Helsinki: Valtioneuvosto, 1925.

Mantere, O. \& Sarva, G. Keskikoulun yleinen historia II. Porvoo: WSOY, 1926.

Mantere, Oskari \& Sarva, Gunnar. Keskikoulun yleinen historia II. Porvoo: WSOY, 1961.

Melander, H. L. Lärobok $i$ allmän historia for realskolor och fruntimmersskolor. Helsingfors: K. E. Holms förlag, 1875.

Modeen, A. E. Oppikirja maantieteessä. Wiipuri: Clouberg ja kump., 1886.

Oppikoulukomitean mietintö. Helsinki: Valtioneuvosto, 1933.

Ora, Y. I. \& Ottelin, A. K. Historian oppikirja keskikouluille III. Helsinki: Otava, 1946.

Peruskoulun opetussuunnitelmakomitean mietintö II. Helsinki: Valtioneuvosto, 1970.

Peruskoulun opetussuunnitelman perusteet. Helsinki: Kouluhallitus, 1985.

Peruskoulun opetussuunnitelman perusteet. Helsinki: Opetushallitus, 1994.

Perusopetuksen opetussuunnitelman perusteet. Helsinki: Opetushallitus, 2004.

Sahlberg, Sigurd. Geografi för lärdomsskolor II. Helsingfors: Söderströms, 1944.

Sahlberg, Sigurd. Lärobok i geografi II. Nykarleby: Författarens förlag, 1931.

Suunnitelmia Suomen kansakoulujen Oppi- ja Lukukirjoja varten. Tarkoitusta varten asetetun komitean Mietintö. Raahe: Rob. Rossander, 1899. 
Tolvanen, Viljo. Kansakoulun maantieto I. Helsinki: Otava, 1927.

Wallin, O. Yleisen historian oppikirja. Kansakouluja varten. Helsinki: Weilin \& Göös, 1898.

Wichmann, V. K. E. \& Rihtniemi, V. Yleisen historian oppikirja seminaareja y.m. opistoja varten. Helsinki: G. W. Edlund, 1914.

\section{B. Research literature and articles}

Alenius, Kari. '"Small nations tied to Russia". Baltic identity conveyed by Finnish schoolbooks from the 1860s to the 2000s.' Faravid 36 (2012): 103-118.

Beller, Manfred. 'Perception, image, imagology.' In Imagology. The cultural construction and literary representation of national characters. A critical survey. Ed. by Manfred Beller and Joep Leerssen. Amsterdam: Rodopi, 2007, 3-16.

Fält, Olavi K. 'Introduction'. In Looking at the Other. Historical study of images in theory and practise. Edited by Kari Alenius, Olavi K. Fält \& Seija Jalagin. Oulu: University of Oulu, 2002, 7-12.

Gergen, Kenneth J. and Gergen, Mary M. Social psychology. New York: Springer Verlag, 1986.

Hemminki, Susanna. Uskonnon värittämä ikivanha kulttuuri, vastakohtaisuuksien sävyttämä jakaantunut yhteiskunta. Intia-kuva suomalaisissa maantiedon oppikirjoissa vuosina 1921-1972. Oulu: Oulun yliopisto, 2005 (unpublished M.A. thesis).

'Juri Derjabin: Puhe Suomen ja Neuvostoliiton ystävyydestä oli liturgiaa.' Helsingin Sanomat 28.10.2012.

Holmén, Janne. Den politiska läroboken. Bilden av USA och Sovjetunionen i norska, svenska och finländska läroböcker under Kalla kriget. Uppsala: Uppsala universitet, 2006.

Kiuasmaa, Kyösti. Oppikoulu 1880-1980. Oppikoulu ja sen opettajat koulujärjestyksestä peruskouluun. Oulu: Pohjoinen, 1982.

Kuikka, Martti T. Suomalaisen koulutuksen vaiheet. Helsinki: Otava, 1991.

Kukkonen, Anu. Pustalla ei ole polkua. Unkari-kuva äidinkielen oppikirjoissa. Jyväskylä: Jyväskylän yliopisto, 2003 (unpublished M.A. thesis).

Livanios, Dimitris. 'The 'sick man' paradox: history, rhetoric and the 'European character' of Turkey.' Journal of Southern Europe and the Balkan, Vol. 8, Number 3 (2006), 299-311.

Ratz, David. 'The Study of Historical Images.' Faravid 31 (2007): 189-220. 
Samuel, Raphael and Thompson, Paul. 'Introduction.' In The Myths We Live By. Ed. by Raphael Samuel and Paul Thompson. London: Routledge, 1990, 1-22.

Rantahäli, Sanna. "Ahkeran vaatimattoman kansan iätön sivistysmaa". Kiinakuva suomalaisissa maantiedon oppikirjoissa vuosina 1921-1972. Oulu: Oulun yliopisto, 2003 (unpublished M.A. thesis).

Tilkanen, Johanna. Vierailulla "epä-Euroopassa". Balkan-kuva suomalaisessa matkakirjallisuudessa maailmansotien välisenä aikana. Turku: Turun yliopisto, 2011 (unpublished M.A. thesis).

Todorova, Maria. Imagining the Balkans. Oxford: Oxford University, 2009.

Vares, Vesa. '"Never satisfactory, according to the Finnish standards". From optimism and interest to disappointment and disillusion: Finnish views on the nations in Eastern Central Europe between the world wars.' The Romanian Journal for Baltic and Nordic Studies, Vol. 3, Issue 2 (2011): 225-246.

Živančević-Sekeruš, Ivana. 'Balkans.' In Imagology. The cultural construction and literary representation of national characters. A critical survey. Ed. by Manfred Beller and Joep Leerssen. Amsterdam: Rodopi, 2007, 103108. 